\title{
Synthesis, Characterization, and Antibacterial Evaluation of a Cost-Effective Endodontic Sealer Based on Tricalcium Silicate-White Portland Cement
}

\author{
Indra Primathena ${ }^{1}$, Denny Nurdin ${ }^{1}$ (D), Hendra Hermawan ${ }^{2,3}$ and Arief Cahyanto ${ }^{4,5, *(D)}$ \\ 1 Department of Conservative Dentistry, Faculty of Dentistry, Universitas Padjadjaran, Bandung 40132, \\ West Java, Indonesia; indra.primathena@fkg.unpad.ac.id (I.P.); denny.nurdin@fkg.unpad.ac.id (D.N.) \\ 2 Department of Mining, Metallurgical and Materials Engineering, Faculty of Sciences and Engineering, \\ Université Laval, Quebec City, QC G1V0A6, Canada; hendra.hermawan@gmn.ulaval.ca \\ 3 Medical Devices and Technology Centre (MEDiTEC), Institute Human Centred Engineering (iHumEn), \\ Universiti Teknologi Malaysia, Johor Bahru 81310, Malaysia \\ 4 Oral Biomaterials Study Centre, Faculty of Dentistry, Universitas Padjadjaran, Bandung 40132, \\ West Java, Indonesia \\ 5 Department of Dental Material Science and Technology, Faculty of Dentistry, Universitas Padjadjaran, \\ Bandung 40132, West Java, Indonesia \\ * Correspondence: arief.cahyanto@fkg.unpad.ac.id; Tel.: +62-22-2504985
}

Citation: Primathena, I.; Nurdin, D.; Hermawan, H.; Cahyanto, A. Synthesis, Characterization, and Antibacterial Evaluation of a CostEffective Endodontic Sealer Based on Tricalcium Silicate-White Portland Cement. Materials 2021, 14, 417. https://doi.org/10.3390/ma14020417

Received: 16 December 2020

Accepted: 12 January 2021

Published: 15 January 2021

Publisher's Note: MDPI stays neutral with regard to jurisdictional claims in published maps and institutional affiliations.

Copyright: () 2021 by the authors. Licensee MDPI, Basel, Switzerland. This article is an open access article distributed under the terms and conditions of the Creative Commons Attribution (CC BY) license (https:// creativecommons.org/licenses/by/ $4.0 /)$.
Abstract: Mineral trioxide aggregate (MTA) is an ideal yet costly endodontic sealer material. Tricalcium silicate-white Portland cement (TS-WPC) seems to have similar characteristics to those of MTA. This work aims to characterize a modified TS-WPC and evaluate its antibacterial properties as a potential endodontic sealer material. The modified TS-WPC was synthesized from a 4:1 mixture of sterilized Indocement TS-WPC and bismuth trioxide using a simple solution method with 99.9\% isopropanol. The mixture was stirred until it was homogenous, centrifuged, and dried. The material was then characterized using infrared spectroscopy, X-ray diffraction, and electron microscopy and subjected to antibacterial evaluation against Enterococcus faecalis using a Mueller-Hinton agar inhibition test. The results showed that the material was characterized by main functional groups of hydroxyls, silicate, bismuth trioxide, and tricalcium silicate, like those of a commercial MTA-based sealer, both tested after hydration. Modified TS-WPC before hydration showed similar powder morphology and size to the commercial one, indicating the ease of manipulation. Both materials exhibited antibacterial activity due to calcium dihydroxide's ability to absorb carbon dioxide, which is essential for the anaerobic $E$. faecalis, with minimum inhibitory effect and bactericidal concentrations of 12,500 ppm and 25,000 ppm, respectively. The modified TS-WPC has the potential to become a cost-effective alternative endodontic sealer material.

Keywords: antibacterial; endodontic sealer; Enterococcus faecalis; mineral trioxide aggregate; tricalcium silicate; white Portland cement

\section{Introduction}

Endodontic treatment is regularly performed to eliminate necrotic tissue and pathogenic bacteria and assist the teeth healing process surrounding the damaged tissue while preventing bacterial reinfection. The treatment consists of three principal biomechanical preparation processes, including cleaning and shaping, followed by the sterilization and obturation of the root canal, known as the endodontic triad, which is the key to a successful root canal treatment $[1,2]$. During this treatment, the root canal cavity must be sterilized from bacterial infection, including the opportunistic Enterococcus, an abnormal flora in the oral cavity habitat that generally colonizes temporarily in individuals with a weak immune system. One of these antibiotic-resistant bacteria, Enterococcus faecalis, has been isolated from various oral conditions, including carious lesions and chronic periodontitis, 
and is associated with persistent apical periodontitis [3,4]. Successful endodontic treatment depends on the selection and application of ingredients or materials for completing obturation, where the root canal is filled with synthetic materials that cover the canal and inhibit the development of the remaining microorganisms $[5,6]$. The root canal filling material is a combination of core material, with gutta-percha as the most widely used one and the golden standard, and a sealer, which is a paste that fills the irregular space between the walls of the gutta-percha and dentin up to the lateral channel $[6,7]$.

An ideal sealer has many features, including being bactericidal, having the capacity to form hermetic density and adhere to the dentin wall, being easy to apply to the root canal without shrinkage after hardening (nor expanding during hardening), and having an adequate working time and consistency $[7,8]$. One of the most used sealer materials is mineral trioxide aggregate (MTA), a bioceramic-based material consisting of various calcium compounds such as calcium silicate $\left(\mathrm{Ca}_{3} \mathrm{SiO}_{5}, \mathrm{Ca}_{2} \mathrm{SiO}_{4}, \mathrm{CaSiO}_{3}\right)$, calcium aluminate $\left(\mathrm{CaAl}_{2} \mathrm{O}_{4}\right)$, and calcium sulfate $\left(\mathrm{CaSO}_{4} \cdot 2 \mathrm{H}_{2} \mathrm{O}\right)[9,10]$. Calcium silicate is known to have excellent broad-spectrum antibacterial power, induces apatite formation in hard tissues, and is thus osteoconductive $[6,11,12]$. Dicalcium silicate and tricalcium silicate produce calcium hydroxide when reacting with water, providing a strong alkalinity and absorbing carbon dioxide, which is essential for the survival of anaerobic bacteria $[10,13,14]$. MTAbased sealers offer advantages in their usability for teeth obturation with an open apex, perforated lesions, and resorption damage due to their ability to harden under humid conditions and induce cementogenesis and dentinogenesis with a strong bond with the dentin wall $[15,16]$. However, their usage is still rare because of their expensive price.

A commercial MTA generally consists of about $75 \mathrm{wt} . \%$ Portland cement, $20 \mathrm{wt} . \%$ bismuth trioxide, and $5 \mathrm{wt} . \%$ calcium sulfate/gypsum as a setting modifier in the powder mixture [17]. Bismuth trioxide $\left(\mathrm{Bi}_{2} \mathrm{O}_{3}\right)$ has been widely used for more than one decade as a radiopacifier in the MTA mixture [18-20]. Many investigations have revealed that inert $\mathrm{Bi}_{2} \mathrm{O}_{3}$ was not involved in the setting reaction and had no effect on Portland cement during the hydration reaction. However, the incorporation of $\mathrm{Bi}_{2} \mathrm{O}_{3}$ as a radiopacifier will produce flaws, increase porosity by leaving more unreacted water in the hydration reaction of the Portland cement, and may reduce the mechanical stability of the sealer [21]. Some preliminary studies showed a compositional similarity of MTA with tricalcium silicate-white Portland cement (TS-WPC), except for the absence of bismuth trioxide in the latter [22-24]. This compositional similarity may give it similar material characteristics that could make TS-WPC an interesting cost-effective alternative to commercial MTA. Therefore, this work aims to evaluate the potential application of a modified TS-WPC for endodontic sealer material by synthesizing and characterizing the material and evaluating its antibacterial properties.

\section{Materials and Methods}

The materials used in this work were TS-WPC powders (Indocement Ltd., Cirebon, Indonesia), bismuth trioxide $\left(\mathrm{Bi}_{2} \mathrm{O}_{3}\right.$, Shanghai Xinglu Chemical Technology Co. Ltd., Shanghai, China), and commercial ProRoot ${ }^{\circledR}$ MTA sealer package (Dentsply Sirona, Ballaigues, Switzerland). All the materials were sterilized under ultraviolet light for $1 \mathrm{~h}$ before use. The synthesis of modified TS-WPC (hereafter called TS-WPC for simplicity) sealer material was conducted by dissolving $80 \mathrm{mg}$ of TS-WPC in $100 \mathrm{~mL}$ of $99.9 \%$ isopropanol, then $20 \mathrm{mg}$ of $\mathrm{Bi}_{2} \mathrm{O}_{3}$ was mixed into the dissolved TS-WPC. The mixture was stirred for $30 \mathrm{~min}$ using a magnetic stirrer at a rotation speed of $400 \mathrm{rpm}$ until it was homogenous, then it transferred into tubes for centrifugation at $1000 \mathrm{rpm}$ for $10 \mathrm{~min}$. As the supernatant was discharged, the pellet was dried under a vacuum for $60 \mathrm{~min}$ to evaporate the isopropanol. The TS-WPC powder samples and the ProRoot ${ }^{\circledR}$ MTA (hereafter called as MTA) for comparison were then characterized by Fourier transform infrared spectroscopy (FT-IR, Spectrum 100, PerkinElmer Inc., Shelton, WA, USA) to obtain an infrared spectrum of absorption, emission, and photoconductivity for different functional groups; $X$-ray diffraction (XRD, D2 Phaser, Bruker Corp., Santa Barbara, CA, USA) to obtain detailed information about 
the crystallographic structures; and scanning electron microscopy and energy dispersive X-ray spectroscopy (SEM-EDS, JSM-6510A, Jeol Ltd., Tokyo, Japan) to observe the surface morphology at high magnification and to analyze its chemical composition.

The powder samples were also subjected to antibacterial evaluation against $E$. faecalis (ATCC 29212) using the Mueller-Hinton Agar method to determine the inhibition zone, the minimum inhibitory concentration (MIC), and the minimum bactericidal concentration (MBC). The inhibition zone was determined by spreading $100 \mu \mathrm{L}$ of E. faecalis suspension onto the MHA surface in $6 \mathrm{~mm}$ diameter wells, then samples of $20 \mathrm{mg}$ TS-WPC and MTA powders were applied onto the wells incubated for $24 \mathrm{~h}$ at $37^{\circ} \mathrm{C}$ in an anaerobic incubator. The tests were performed in triplicate, and the inhibition zone diameter was then measured using a millimeter-scale caliper as the average of three tests. To evaluate the MIC, both samples were diluted in $9 \% \mathrm{NaCl}$ to obtain a range of concentration up to $400,000 \mathrm{ppm}$. Then, $100 \mu \mathrm{L}$ of each sample was inserted into the designated 96-well microplates, where $10 \mu \mathrm{L}$ of Mueller-Hinton broth containing bacteria was then added, followed by incubation at $37^{\circ} \mathrm{C}$ for $24 \mathrm{~h}$, and ended by measuring the turbidity in a microplate reader. The MIC was indicated by wells containing the lowest concentration that was still able to inhibit bacterial growth. The MBC was evaluated by preparing two more concentrated solutions than the MIC and two more dilute solutions than the MIC, which were sub-cultured (planting) on the MHA media and incubated at $37^{\circ} \mathrm{C}$ for $24 \mathrm{~h}$. This planting was performed to overcome the microplate reader's ability to read the plate's dilution turbidity by measuring its optical density alone, without detecting the separate turbidity caused by the two sample materials' different densities. The MBC was determined from the agar media with no bacterial colony.

\section{Results}

The TS-WPC and MTA samples presented some similarities in their IR spectra before and after hydration (Figure 1a). Hydration was performed by reacting the samples with distilled water to simulate conditions during which a sealer is applied to a root canal. Table 1 details the association of each peak with its corresponding functional group and chemical bond. Before hydration, both the samples showed strong peaks at $883.67 \mathrm{~cm}^{-1}$ (TS-WPC) and $876.40 \mathrm{~cm}^{-1}$ (MTA), associated with the $\mathrm{Si}-\mathrm{C} / \mathrm{C}=\mathrm{C}$ bond of the alkenes group. Weaker peaks were identified as Si-O bonds at 1144.89 and $1153.90 \mathrm{~cm}^{-1}$ and as C$\mathrm{H} / \mathrm{C}-\mathrm{O}$ bonds (alkanes/alkanols) at 1486.18 and $1456.61 \mathrm{~cm}^{-1}$ for each TS-WPC and MTA sample, respectively. Beyond the fingerprint band, peaks associated with the $\mathrm{Si}-\mathrm{H}$ bond occurred at $2359 \mathrm{~cm}^{-1}$ for both samples. After hydration, a peak appeared at $3395 \mathrm{~cm}^{-1}$ on both samples' IR spectra, indicating the presence of hydroxide compounds such as $\mathrm{Ca}(\mathrm{OH})_{2}$. The alkenes group's presence was stronger in both samples, as indicated by the high intensity peaks of C-H/C-O at $1415 \mathrm{~cm}^{-1}$ and $\mathrm{Si}-\mathrm{C} / \mathrm{C}=\mathrm{C}$ at $871 \mathrm{~cm}^{-1}$.

Further characterization by XRD identified the presence of four compounds in both samples before hydration (Figure $1 \mathrm{~b})$, which are tricalcium silicate $\left(\mathrm{Ca}_{3} \mathrm{SiO}_{5}\right)$, bismuth trioxide $\left(\mathrm{Bi}_{2} \mathrm{O}_{3}\right)$, dicalcium silicate $\left(\mathrm{Ca}_{2} \mathrm{SiO}_{4}\right)$, and tricalcium aluminate $\left(\mathrm{Ca}_{3} \mathrm{Al}_{2} \mathrm{O}_{6}\right)$. After hydration, the four compounds' peaks were still present with the new appearance of calcium hydroxide $\left(\mathrm{Ca}(\mathrm{OH})_{2}\right)$ peaks. The peaks appeared very weak due to the relatively short contact time $(30 \mathrm{~min})$ between the samples and water during hydration. Both the XRD and FT-IR results confirmed a chemical similarity between the TS-WPC and MTA samples, while SEM observation showed their morphological similarity (Figure 2). Both powders had an octahedral shape, with an average size of $5 \mu \mathrm{m}$, and elemental bismuth was present on the powders as $\mathrm{Bi}_{2} \mathrm{O}_{3}$.

The bacterial inhibition zones of the two tested samples indicated a similar measured diameter (Figure 3). The average diameter of the formed clear area was $15.33 \mathrm{~mm}$ for the TS-WPC and $15.36 \mathrm{~mm}$ for the commercial MTA. Table 2 shows that some E. faecalis colonies still existed at the concentration of $12,500 \mathrm{ppm}$. The bacteria were killed and declared to be depleted at the concentration of $25,000 \mathrm{ppm}$. 

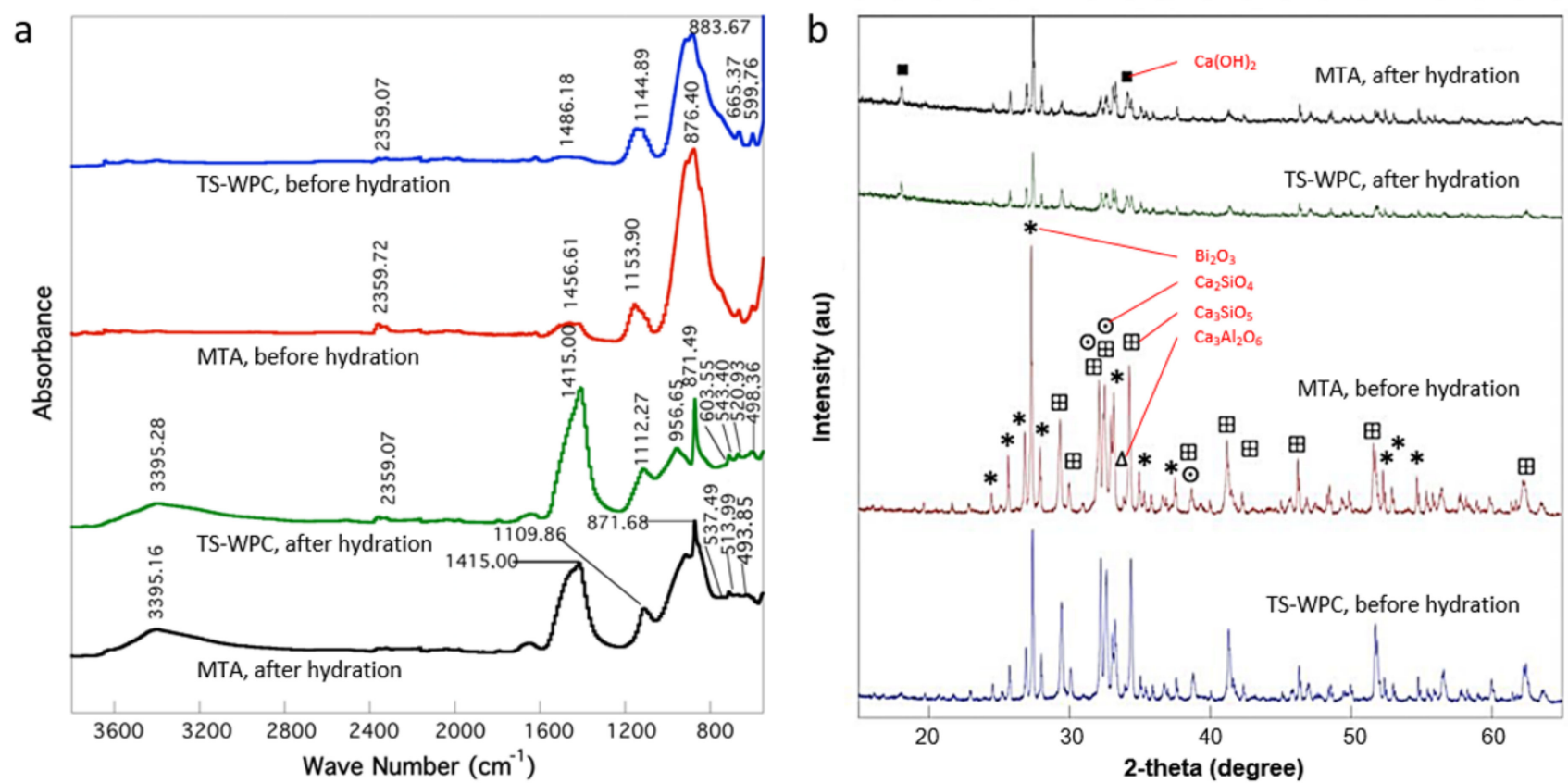

Figure 1. (a) FT-IR spectra and (b) XRD pattern results of the tricalcium silicate-white Portland cement (TS-WPC) and the commercial mineral trioxide aggregate (MTA) samples before and after hydration.

Table 1. FT-IR peak identification.

\begin{tabular}{|c|c|c|c|}
\hline \multicolumn{2}{|c|}{ TS-WPC } & \multicolumn{2}{|r|}{ MTA } \\
\hline Wavenumber $\left(\mathrm{cm}^{-1}\right)$ & Bond/Type of Functional Group & Wavenumber $\left(\mathrm{cm}^{-1}\right)$ & Bond/Type of Functional Group \\
\hline \multicolumn{4}{|c|}{ Before hydration } \\
\hline $\begin{array}{l}599.75 \\
665.37\end{array}$ & C-H (alkanes) & & \\
\hline 883.67 & Si-C $/ C=C$ (alkenes) & 876.40 & Si-C/C=C (alkenes) \\
\hline 1144.89 & $\mathrm{Si}-\mathrm{O}$ & 1153.90 & $\mathrm{Si}-\mathrm{O}$ \\
\hline 1486.18 & C-H (alkanes) /C-O (alkanols) & 1456.61 & C-H (alkanes) /C-O (alkanols) \\
\hline 2359.07 & $\mathrm{Si}-\mathrm{H}$ & 2359.72 & $\mathrm{Si}-\mathrm{H}$ \\
\hline \multicolumn{4}{|c|}{ After hydration } \\
\hline 451.71 & & 436.77 & \\
\hline 467.69 & $\begin{array}{l}\text { Aromatic group } \\
\text { (S-O)/sulfate inic }\end{array}$ & 445.38 & \\
\hline 498.36 & (S-U) / sulfate ionic bonds $\left(\mathrm{SU}_{4}\right)$ & 466.56 & $\begin{array}{l}\text { Aromatic group } \\
(\mathrm{S}-\mathrm{O}) / \text { sulfate ionic bonds }\left(\mathrm{SO}_{4}\right)^{-}\end{array}$ \\
\hline & & $\begin{array}{l}475.90 \\
493.85\end{array}$ & \\
\hline 520.93 & Fingerprint band/Si-O & 513.99 & Fingerprint band/Si-O \\
\hline 543.40 & (bending) $/ \mathrm{Ca}=\mathrm{O}$ & 537.49 & (bending) $/ \mathrm{Ca}=\mathrm{O}$ \\
\hline 603.55 & Fingerprint band & & \\
\hline 871.49 & $\mathrm{Si}-\mathrm{C} / \mathrm{C}=\mathrm{C}$ (alkenes) & 871.68 & Si-C $/ C=C$ (alkenes) \\
\hline 956.65 & Si-O (stretching) & & \\
\hline 1112.27 & $\mathrm{Si}-\mathrm{O}$ & 1109.86 & Si-O \\
\hline 1408.59 & C-H (alkanes)/C-O (alkanols) & 1415.00 & C-H (alkanes) /C-O (alkanols) \\
\hline 2359.07 & $\mathrm{Si}-\mathrm{H}$ & & \\
\hline 3395.28 & $\mathrm{O}-\mathrm{H}$ & 3395.16 & $\mathrm{O}-\mathrm{H}$ \\
\hline
\end{tabular}



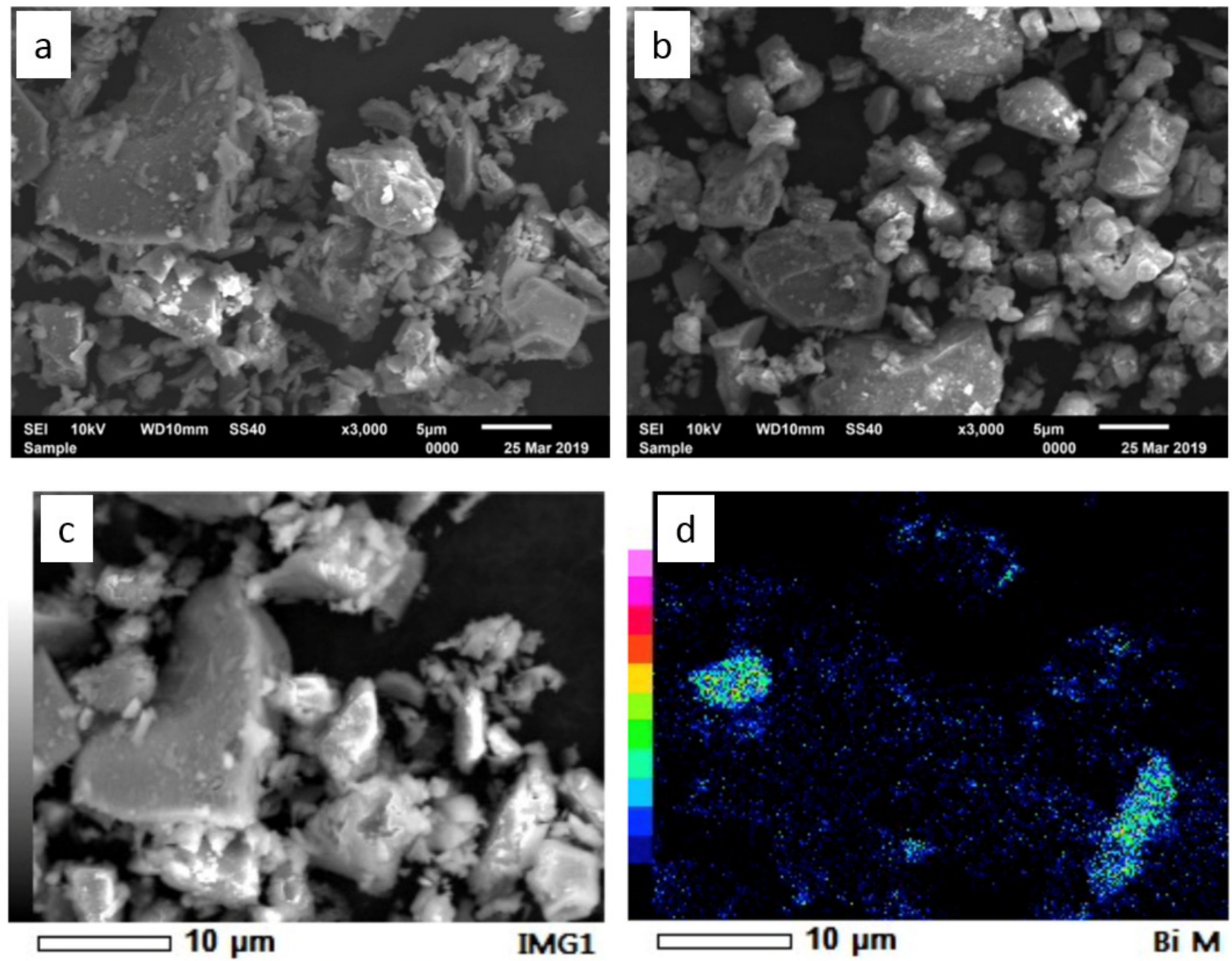

Figure 2. Secondary electron micrographs of (a) TS-WPC and (b) MTA samples, (c) backscattered electron micrograph of TS-WPC, (d) elemental mapping of bismuth on the TS-WPC sample. All the sample pictures are from before hydration.

Table 2. Minimum bactericidal concentration of the TS-WPC samples.

\begin{tabular}{|c|c|c|c|c|c|c|c|c|c|c|c|c|c|}
\hline \multicolumn{7}{|c|}{ Observation } & \multirow{2}{*}{$\begin{array}{c}\begin{array}{c}12,500 \\
\text { ppm }\end{array} \\
7\end{array}$} & \multirow{2}{*}{$\begin{array}{c}\begin{array}{c}25,000 \\
\text { ppm }\end{array} \\
8\end{array}$} & \multirow{2}{*}{$\begin{array}{c}\begin{array}{c}50,000 \\
\text { ppm }\end{array} \\
9\end{array}$} & \multirow{2}{*}{$\begin{array}{c}\begin{array}{c}100,000 \\
\text { ppm }\end{array} \\
10\end{array}$} & \multirow{2}{*}{$\begin{array}{c}200,000 \\
\text { ppm }\end{array}$} & \multirow{2}{*}{$\begin{array}{c}400,000 \\
\text { ppm }\end{array}$} & \multirow{2}{*}{ Notes } \\
\hline No. & 1 & 2 & 3 & 4 & 5 & 6 & & & & & & & \\
\hline $\mathrm{A}$ & - & - & + & + & + & + & + & - & - & - & - & - & \\
\hline B & - & - & + & + & + & + & + & - & - & - & - & - & \\
\hline $\mathrm{C}$ & - & - & + & + & + & - & - & - & - & - & - & - & \\
\hline $\mathrm{D}$ & - & - & - & - & - & - & - & - & - & - & - & - & * \\
\hline $\mathrm{E}$ & - & - & + & + & + & + & - & - & - & - & - & - & \\
\hline $\mathrm{F}$ & - & - & + & + & + & + & + & - & - & - & - & - & \\
\hline G & - & - & + & + & + & + & + & - & - & - & - & - & \\
\hline $\mathrm{H}$ & - & - & - & - & - & - & - & - & - & - & - & - & $* *$ \\
\hline
\end{tabular}

Notes: * Media mixed with MTA with no bacteria; ${ }^{* *}$ media mixed with TS-WPC, with no bacteria; ** control media without testing materials and bacteria (100 mL of $\mathrm{MHB})$. Letters A-H and numbers 1-12 indicate the tested plates and sealer concentrations, respectively. A negative sign (-) means the bacterial colony died, positive sign (+) means the bacterial colony survived. 

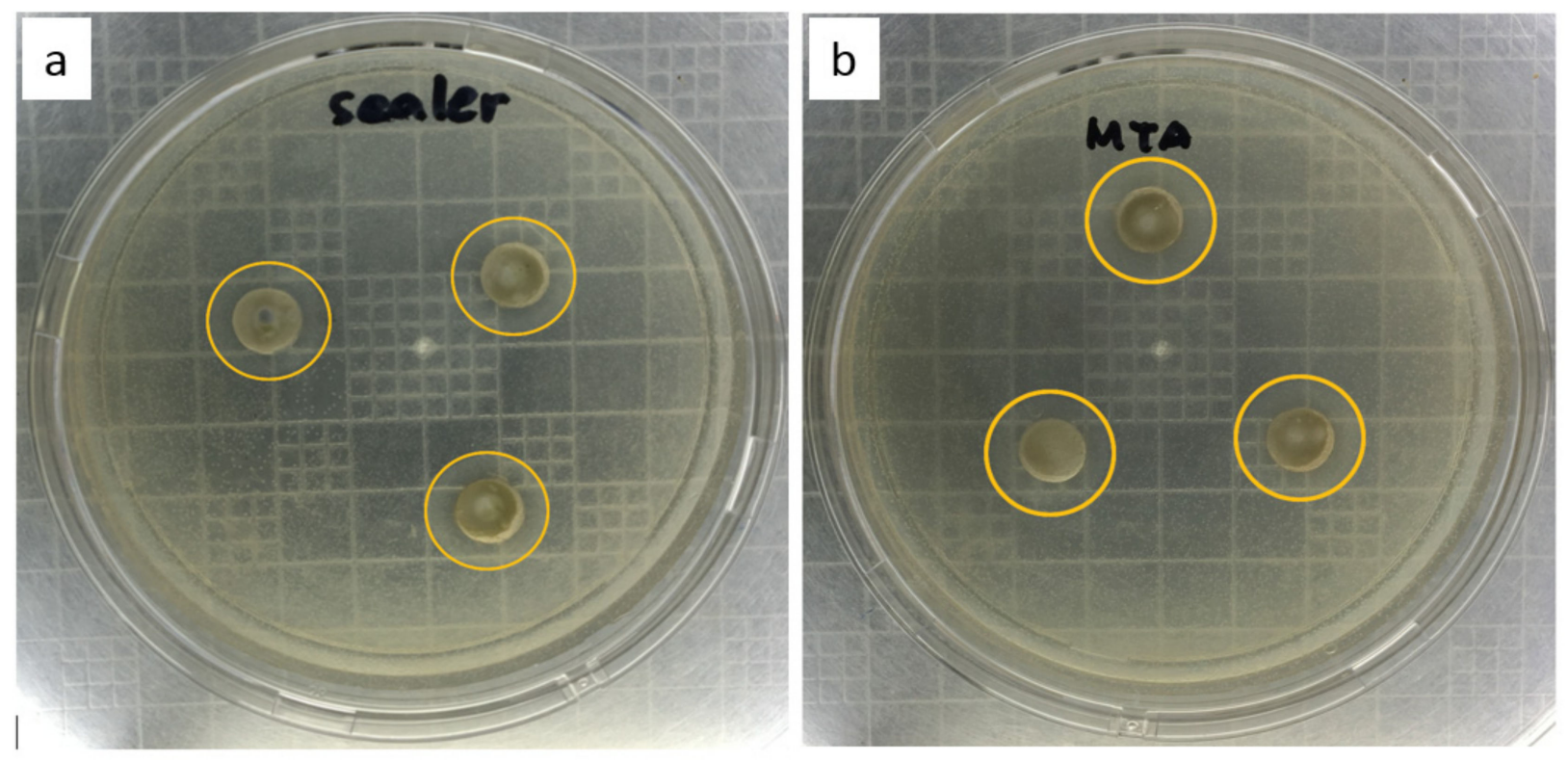

Figure 3. Bacterial inhibition zone (yellow circle) of (a) TS-WPC and (b) MTA samples against E. faecalis.

\section{Discussion}

The TS-WPC powder samples were characterized using FT-IR, XRD, and SEM-EDS, along with samples of the MTA as a comparison. The characterization results showed some similarities between the lab-made TS-WPC samples and the commercial MTA sealer in terms of chemistry, crystallinity, and granulometry. On the IR spectra, both samples presented strong peaks of the $\mathrm{Si}-\mathrm{C} / \mathrm{C}=\mathrm{C}$ bond, weaker peaks of the $\mathrm{Si}-\mathrm{O}$ and $\mathrm{C}-\mathrm{H} / \mathrm{C}-\mathrm{O}$ bonds, and beyond the fingerprint band peaks of the $\mathrm{Si}-\mathrm{H}$ bond. Once hydrated, new peaks of $\mathrm{Ca}(\mathrm{OH})_{2}$ appeared while preserving the high intensity peaks of $\mathrm{C}-\mathrm{H} / \mathrm{C}-\mathrm{O}$ and $\mathrm{Si}-\mathrm{C} / \mathrm{C}=\mathrm{C}$ bonds. The appearance of $\mathrm{Ca}(\mathrm{OH})_{2}$ was again identified on the $\mathrm{XRD}$ patterns of hydrated samples, while before hydration four main compounds were identified as $\mathrm{Ca}_{3} \mathrm{SiO}_{5}, \mathrm{Bi}_{2} \mathrm{O}_{3}, \mathrm{Ca}_{2} \mathrm{SiO}_{4}$, and $\mathrm{Ca}_{3} \mathrm{Al}_{2} \mathrm{O}_{6}$. These results were in line with the previous research that confirmed the presence of $\mathrm{Ca}(\mathrm{OH})_{2}$ [25]. Calcium hydroxide $\left(\mathrm{Ca}(\mathrm{OH})_{2}\right)$ has long been used as one of the most effective root canal medicaments. Calcium hydroxide has a working action by releasing $\mathrm{Ca}^{2+}$ ions which play a role in the mineralization process of tissues and $\mathrm{OH}^{-}$ions, which can provide an antimicrobial effect by increasing the $\mathrm{pH}$ so that an alkaline environment is formed, which causes most of the microorganisms in the root canals to be unable to survive [26]. The characterization results clearly showed that TS-WPC with added $20 \mathrm{wt} . \% \mathrm{Bi}_{2} \mathrm{O}_{3}$ as a radiopacifier had the same configuration of peaks as that of the commercial MTA, and both materials were compositionally similar. These similar material characteristics should provide similar properties-i.e., antibacterial capabilities. In terms of granulometry, both samples have octahedral shape powders with an average size of $5 \mu \mathrm{m}$, and elemental bismuth was evidently present on the powders as $\mathrm{Bi}_{2} \mathrm{O}_{3}$, as observed in the work of Bedoya-Hincapie et al. [27].

The usage of endodontic sealers' to perform root canal fillings in obturation procedures is an established mainstay in endodontics and plays a crucial role in the success of the treatment. Therefore, these materials should exhibit a set of characteristics that allow successful root canal filling with the resolution of periapical inflammatory and/or infectious processes and prevent further microbial contamination [28]. Based on the results of the antibacterial evaluation against E. faecalis using the Mueller-Hinton Agar method, the two samples presented similar diameters of bacterial inhibition zones of around $15 \mathrm{~mm}$, falling within the classification of intermediate sensitivity, with a diameter between 14 and $22 \mathrm{~mm}$ [29]. The consistent dense sealer after setting time within $24 \mathrm{~h}$ is one of the limiting factors for the diffusion process of antibacterial agent to the further agar area. Therefore, 
this TS-WPC sealer's application will require direct contact in the root canal cavity to eliminate bacteria optimally [29-31]. The TS-WPC sample achieved its minimum inhibitory concentration (MIC) at 12,500 ppm, while its minimum bactericidal concentration (MBC) was reached at 25,000 ppm. This MBC value is interestingly far below the concentration commonly used in root canal sealer applications.

The antibacterial capability of both samples can be attributed to the presence of a $\mathrm{Ca}(\mathrm{OH})_{2}$ compound that created a strong alkaline condition and provided hydroxyl ions, which was consistent with the other finding that the application of intracanal medicaments containing $\mathrm{Ca}(\mathrm{OH})_{2}$ compounds was a competent of forming negative cultures of $E$. faecalis $[32,33]$. Most pathogenic bacteria in the root canal cannot survive the strong alkaline conditions, with a $\mathrm{pH}$ of around 12.5 , produced by $\mathrm{Ca}(\mathrm{OH})_{2}$. Generally, bacteria will be eliminated sometime after contact with $\mathrm{Ca}(\mathrm{OH})_{2}$, as they can only tolerate a $\mathrm{pH}$ range between 6 and 9 [34]. The high $\mathrm{pH}$ conditions created by $\mathrm{Ca}(\mathrm{OH})_{2}$ inhibit enzyme activity during bacterial cell metabolism [35]. Alkalinity induces the breakdown of ionic bonds that maintain the tertiary structure of proteins, thus only covalent bonds are maintained leading to the formation of an irregular bond of polypeptide chains. These changes eventually cause the loss of the enzymes' biological activity, thus damaging the cell metabolism [30].

The second antibacterial capability of $\mathrm{Ca}(\mathrm{OH})_{2}$ comes from the hydroxyl ions, which are high free radical oxidants with strong reactivity toward bacterial cytoplasmic membrane [31]. Bacterial cytoplasmic membranes have essential functions in cell defense mechanisms, such as selective permeability and fluid transport; secretion from the hydrolysis exoenzyme; and delivering enzymes and molecules that function in DNA biosynthesis, cell wall polymers, and membrane lipids [30]. Hydroxyl ions induce lipid peroxidation, which damages phospholipids and the cell membrane structure. Hydroxyl ions avert hydrogen atoms from unsaturated fatty acids in producing free radicals from lipids. These free radicals react with oxygen and form peroxide lipid radicals that avert other hydrogen atoms from secondary fatty acids to re-produce other lipid peroxides. Peroxide acts as a free radical that automatically initiates the catalysis chain reaction, losing more fatty acids and sustaining more severe membrane damage. Hydroxyl ions also react with bacterial DNA and induce the division of DNA from the chain structure unity that can cause the loss of bacterial genetic code, leading to a failure in DNA replication, and thus cell activity does not occur [30]. Another contributing factor to the antibacterial capability of $\mathrm{Ca}(\mathrm{OH})_{2}$ is its ability to absorb $\mathrm{CO}_{2}$ stored in the periradicular tissue of the root canal cavity, eliminating the essential atmosphere for anaerobic bacterial survival of bacteria such as E. faecalis $[34,35]$.

This modified TS-WPC could become a cost-effective alternative endodontic sealer material once its biocompatibility is confirmed. It may become one among many alternative therapies for treating root canal problems including the easily accessible stem cells that can be isolated from various tissues of the oral cavity and become sources for bone and dental regeneration [36].

\section{Conclusions}

A modified tricalcium silicate-white Portland cement (TS-WPC) was synthesized using a simple solution method and possessed similar material characteristics and antibacterial properties to those of a commercial mineral trioxide aggregate (MTA)-based sealer material. The TS-WPC was characterized by powder morphology, hydroxyl and silicate groups, and bismuth trioxide and tricalcium silicate phases like those of a commercial MTA-based sealer. The TS-WPC and MTA samples exhibited antibacterial activity against the anaerobic E. faecalis bacteria, with minimum inhibitory and killing concentrations of $12,500 \mathrm{ppm}$ and 25,000 ppm, respectively. Although both materials' TS-WPC and the commercial MTA were proven to be compositionally similar, further studies of TS-WPC are awaited based on these findings to improve its mechanical stability and biocompatibility. The modified TS-WPC has the potential to become a cost-effective alternative endodontic sealer material. 
Author Contributions: Conceptualization, A.C.; methodology, A.C., I.P., D.N.; validation, A.C.; formal analysis, A.C., H.H.; writing-Original draft preparation, I.P.; writing-Review and editing, A.C., I.P., D.N., H.H.; supervision, A.C.; funding acquisition, D.N., A.C. All authors have read and agreed to the published version of the manuscript.

Funding: This research was funded by Universitas Padjadjaran through the Internal Research Grant Program No. 2224/UN6.F/PM/2018 (D.N. and A.C.), by the National Sciences and Engineering Research Council of Canada through Discovery Grant, and the Universiti Technology Malaysia's research fellow scheme (H.H.).

Institutional Review Board Statement: Not applicable.

Informed Consent Statement: Not applicable.

Data Availability Statement: No new data were created or analyzed in this study. Data sharing is not applicable to this article.

Conflicts of Interest: The authors declare no conflict of interest.

\section{References}

1. Berman, L.H.; Hargreaves, K.M. Cohen's Pathways of the Pulp, 11th ed.; Mosby-Elsevier: Saint Louis, MO, USA, 2016 ; pp. 139-161.

2. Torabinejad, M.; Walton, R. Endodontics: Principles and Practice, 4th ed.; Saunders-Elsevier: Philadelphia, PA, USA, $2008 ;$ pp. 61-82.

3. Murray, B.E. Vancomycin-resistant enterococcal infections. N. Eng. J. Med. 2000, 342, 710-721. [CrossRef] [PubMed]

4. Zhu, X.; Wang, Q.; Zhang, C.; Cheung, G.S.; Shen, Y. Prevalence, phenotype, and genotype of Enterococcus faecalis isolated from saliva and root canals in patients with persistent apical periodontitis. J. Endod. 2010, 36, 1950-1955. [CrossRef] [PubMed]

5. Al-Haddad, A.; Kutty, M.G.; Abu Kasim, N.H.; Che Ab Aziz, Z.A. Physicochemical properties of calcium phosphate-based coating on gutta-percha root canal filling. Int. J. Polym. Sci. 2015, 2015, 414521. [CrossRef]

6. Singh, H.; Markan, S.; Kaur, M.; Gupta, G. Endodontic sealers: Current concepts and comparative analysis. Open Dent. J. 2015, 2, 32-37. [CrossRef]

7. Orstavik, D. Materials used for root canal obturation: Technical, biological and clinical testing. Endod. Top. 2005, 12, 25-38. [CrossRef]

8. Cavenago, B.C.; Duarte, M.A.; Ordinola-Zapata, R.; Marciano, M.A.; Carpio-Perochena, A.E.; Bramante, C.M. Interfacial adaptation of an epoxy-resin sealer and a self-etch sealer to root canal dentin using the system $\mathrm{B}$ or the single cone technique. Braz. Dent. J. 2012, 23, 205-211. [CrossRef]

9. Darvell, B.W.; Wu, R.C.T. "MTA"-An hydraulic silicate cement: Review update and setting reaction. Dent. Mater. 2011, 27, 407-422. [CrossRef]

10. Chiang, T.Y.; Ding, S.J. Comparative physicochemical and biocompatible properties of radiopaque dicalcium silicate cement and mineral trioxide aggregate. J. Endod. 2010, 36, 1683-1687. [CrossRef]

11. Liu, X.; Morra, M.; Carpi, A.; Li, B. Bioactive calcium silicate ceramics and coatings. Biomed. Pharmacother. 2008, 62, 526-529. [CrossRef]

12. Gandolfi, M.G.; Ciapetti, G.; Taddei, P.; Perut, F.; Tinti, A.; Cardoso, M.V.; Van Meerbeek, B.; Prati, C. Apatite formation on bioactive calcium-silicate cements for dentistry affects surface topography and human marrow stromal cells proliferation. Dent. Mater. 2010, 26, 974-992. [CrossRef]

13. Marão, H.F.; Panzarini, S.R.; Aranega, A.M.; Sonoda, C.K.; Poi, W.R.; Esteves, J.C.; Silva, P.I. Periapical tissue reactions to calcium hydroxide and MTA after external root resorption as a sequela of delayed tooth replantation. Dent. Traumatol. 2012, 28, 306-313. [CrossRef] [PubMed]

14. Pelisser, F.; Steiner, L.R.; Bernardin, A.M. Recycling of porcelain tile polishing residue in portland cement: Hydration efficiency. Environ. Sci. Technol. 2012, 46, 2368-2374. [CrossRef] [PubMed]

15. Rodríguez-Lozano, F.J.; López-García, S.; García-Bernal, D.; Tomás-Catalá, C.J.; Santos, J.M.; Llena, C.; Lozano, A.; Murcia, L.; Forner, L. Chemical composition and bioactivity potential of the new Endosequence BC Sealer formulation HiFlow. Int. Endod. J. 2020, 53, 1216-1228. [CrossRef] [PubMed]

16. Güven, E.P.; Taşlı, P.N.; Yalvac, M.E.; Sofiev, N.; Kayahan, M.B.; Sahin, F. In vitro comparison of induction capacity and biomineralization ability of mineral trioxide aggregate and a bioceramic root canal sealer. Int. Endod. J. 2013, 46, 1173-1182. [CrossRef] [PubMed]

17. Bakland, L.K. Management of traumatically injured pulps in immature teeth using MTA. J. Calif. Dent Assoc. 2000, 28, 855-858. [PubMed]

18. Witherspoon, D.E.; Ham, K. One visit apexification: Technique for inducing root-end barrier formation in apical closures. Pract. Proced. Aesthet. Dent. 2001, 13, 455-462. [PubMed]

19. Torabinejad, M.; White, D.J. Tooth Filling Material and Method of Use. U.S. Patent No. 5, 415, 547, 1995.

20. Main, C.; Mirzayan, N.; Shabahang, S.; Torabinejad, M. Repair of root perforations using mineral trioxide aggregate: A long term study. J. Endod. 2004, 30, 80-83. [CrossRef] 
21. Coomaraswamy, K.S.; Lumley, P.J.; Hofmann, M.P. Effect of bismuth oxide radioopacifier content on the material properties of an endodontic portland cement-based (MTA-like) system. J. Endod. 2007, 33, 295-298.

22. Dammaschke, T.; Gerth, H.U.V.; Züchner, H.; Schäfer, E. Chemical and physical surface and bulk material characterization of white ProRoot MTA and two Portland cements. Dent. Mater. 2005, 21, 731-738.

23. Primathena, I.; Nurdin, D.; Adang, R.A.; Cahyanto, A. Composition and functional groups evaluation of Indonesian grey portland cement as material for dental application. Key Eng. Mater. 2018, 782, 256-261. [CrossRef]

24. Nurdin, D.; Primathena, I.; Adang, R.A.; Cahyanto, A. Comparison of chemical composition between Indonesian white portland cement and MTA as dental pulp capping material. Key Eng. Mater. 2019, 829, 34-39. [CrossRef]

25. Li, Q.; Coleman, N.J. The hydration chemistry of ProRoot MTA. Dent. Mater. J. 2015, 34, 458-465. [CrossRef] [PubMed]

26. Hasheminia, S.; Norozynasab, S.; Feizianfard, M. The Effect of Three Different Calcium Hydroxide Combinations on Root Dentine Microhardness. Res. J. Biol. Sci. 2009, 4, 121-125.

27. Bedoya-Hincapie, C.M.; Pinzón Cárdenas, M.J.; Alfonso, E.; Restrepo Parra, E. Physical-chemical properties of bismuth and bismuth oxides: Synthesis, characterization and application. Dyna 2012, 79, 139-148.

28. Fonseca, D.A.; Paula, A.B.; Marto, C.M.; Coelho, A.; Paulo, S.; Martinho, J.P.; Carrilho, E.; Ferreira, M.M. Biocompatibility of Root Canal Sealers: A Systematic Review of In Vitro and In Vivo Studies. Materials 2019, 12, 4113. [CrossRef] [PubMed]

29. Clinical and Laboratory Standards Institute. M100: Performance Standards for Antimicrobial Susceptibility Testing, 24th ed.; CLSI: Annapolis Junction, MD, USA, 2014.

30. Mohammadi, Z.; Shalavi, S.; Yazdizadeh, M. Antimicrobial activity of calcium hydroxide in endodontics: A review. Chonnam Med. J. 2012, 48, 133-140. [CrossRef] [PubMed]

31. Siqueira, J.F., Jr.; Lopes, H.P. Mechanisms of antimicrobial activity of calcium hydroxide: A critical review. Int. Endod. J. 1999, 32, 361-369. [CrossRef]

32. Sjogren, U.; Figdor, D.; Spangberg, L.; Sundqvist, G. The antimicrobial effect of calcium hydroxide as a short-term intracanal dressing. Int. Endod. J. 1991, 24, 119-125. [CrossRef]

33. Estrela, C.; Rodrigues de Araújo Estrela, C.; Bamman, L.L.; Pecora, J.D. Two methods to evaluate the antimicrobial action of calcium hydroxide paste. J. Endod. 2001, 27, 12-15. [CrossRef]

34. Han, G.Y.; Park, S.H.; Yoon, T.C. Antimicrobial activity of $\mathrm{Ca}(\mathrm{OH})_{2}$ containing pastes with Enterococcus faecalis in vitro. J. Endod. 2001, 27, 328-332. [CrossRef]

35. Estrela, C.; Pécora, J.D.; Silva, R.S. pH analysis of vehicles and calcium hydroxide pastes. Braz. Endod. J. 1998, 3, $41-47$.

36. Capparè, P.; Tetè, G.; Sberna, M.T.; Panina-Bordignon, P. The emerging role of stem cells in regenerative dentistry. Curr. Gene Ther. 2020, 20, 259-268. 